\title{
Ecotext of Environmental Treatment and Preservation of Springs -Upstream River in Tenganan Pegringsinan Village
}

\author{
Mirsa Umiyati, Aron Meko Mbete \\ \{mirsa.umiyati2@gmail.com\}
}

Universitas Warmadewa

\begin{abstract}
There are some elements of culture in all languages, especially the Balinese. Also, the knowledge of the environment are encoded, stored, and inherited in all language. In addition, most verbal texts in Balinese have the touch of knowledge and experience, including the traditional techniques of speech in the community which preserve the natural resources diversity in the environment, especially in the springs-upstream rivers. Tenganan Pegringsingan, which is one of the original villages, also known as baliaga, has the intended local wisdom. Similarly, there is need to maintain and guard the water resources in the springsupstream rivers environment, considering the fact that humans cannot live without it. Based on this background, the speech community in the village has a regulation or awig-awig in the form of verbal texts with ecological function. Therefore, a study into the functioning, compliance, or non-compliance of speech community towards water ecological wisdom is very important. Hence, the acquisition of facts and information about the functional relations of language, water culture, and the environment in terms of preserving the springs-upstream river are the basis for the formulation of a conservation model. Also, the comparative advantage of the preservation model, based on local wisdom, is not only for the natural diversity of the Dewata Island, but as well beneficial for the development of this model in the Archipelago, specifically to support national ecotourism with global competitiveness. The eco-text study in the upstream river of Tenganan Pegringsinan traditional village revealed there were 31 noun ecolexicons. Furthermore, the total verb ecolexicons found were 11 words. However, the Provincial Regulation of Bali Province Number 4 of 2019 on traditional villages in Bali, stated that there are 27 nouns in the Tenganan Pegringsinan village. Therefore, there is a need for collaboration between various parties to preserve the existing eco-texts in the village.
\end{abstract}

Keywords: ecotext, upstream river ecolexicon, awig-awig, local wisdom

\section{Pendahuluan}


Sebagai destinasi pariwisata global yang sudah sangat terkenal, kelestarian alam dan lingkungan hidup Pulau Dewata menjadi sebuah keniscayaan yang harus tetap dirawat sepanjang zaman. Tuntutan fundamental sekaligus tuntunan filosofi Trihita Karana demi keharmonisan nilai-nilai kehidupan, layak dipatuhi dan diaktualisasi. Kekuatan sumber daya Adat dan Agama Hindu Dharma, serta ketegaran lapisan tradisi asli-asali, adalah sumber daya kehidupan yang menjadi "Roh" penggerak perawatan lingkungan. Kekuatan sistem nilai itu menjadi faktor dominan yang sangat menentukan tetap terwaris dan lestarinya alam dan kebudayaan Bali. Keharmonisan tata nilai itu tidak hanya demi pariwisata melainkan demi kehidupan bangsa Indonesia sebagai bangsa yang unggul dengan alam dan budayanya.

Desa Adat Tenganan Pegringsingan, Karangasam, adalah salah satu kawasan destinasi dengan keunikan dan keunggulannya tersendiri. Nuansa adat dan tradisi berbasis ketahanan nilai-nilai keasliannya dan dengan pola pemukimannya yang unik, menjadikan desa tersebut selalu menarik untuk dilawati oleh para wisatawan dari pelbagai negeri. Selain keunikan tradisi dan seni atraktifnya yang heroic, lingkungan alamnya yang tetap "asli" dan asri, sumberdaya alam berbasis kearifan lokalnya itu patut dikaji dan dipahami secara akademik. Dalam kerangka penalaran ini, salah satu elemen kebudayaan Bali yakni Bahasa Bali, khususnya teks-teks yang mewadahi awig-awig desa pekramannya, secara khusus tentang perawatan dan pelestarian ekologi mata air-hulu sungai, sangat penting untuk dikaji, didalami, dan dimaknai. Dengan demikian, bahasa Bali sebagai media perekam dan pewaris kebudayaan Bali dalam pelbagai seginya, sangat penting dan strategis untuk juga dilestarikan. Selain menjadi penanda jati diri, bahasa Bali, secara khusus dialek baliaga, adalah perekat rasa persatuan dan kesatuan masyarakat etnik Bali, bagian utuh dari Negara-bangsa Indonesia yang majemuk. Rekaman dan warisan elemen-elemen budaya leluhur yang sangat kaya dan potensial itu, secara historik, berbasiskan pengalaman interelasi, interaksi, dan interdependensi guyub tutur dengan lingkungan alam, dan dengan lingkungan keairan khususnya. Dalam konteks ini, lingkungan mata air-hulu sungai di kawasan Desa Tenganan Pegringsingan sebagai sumberdaya alam dalam rawatan budaya dijadikan fokus kajian. Sebagai bagian dari kebudayaan Bali yang sangat luhur itu, budaya keairan khususnya makna dan nilai mata air- hulu sungai, menjadi ruang hidup, penghidupan, dan kehidupan berdimensi spiritual dan ragawi-alami yang layak dipahami secara mendalam. Untuk itu fungsi tek-teks berbahasa Bali sebagai fakta ekologis menjadi tumpuan pengkajian. Dikaitkan dengan teks verbal bahasa Bali, keberfungsian teks sebagai fakta kebahasaan dalam praktik sasio-ekologis di lingkungan khusus mata air-hulu sungai menjadi focus telaah. Sebagai sumber pelestari Subak, niscaya fakta dan informasi di balik teks verbal itu layak dan penting digali.

Ada dua hal penting yang layak didalami. Pertama, fakta keterpahaman mendalam dan kepatuhan guyub tutur, yang juga guyub kultur keairan yang setia merawat mata air -hulu sungai. Kedua, fakta dinamika dan perubahan elemen budaya dalam kaitan dengan ketidakpatuhan atas kandungan makna dan kekuatan nilai tekstual verbal bahasa Bali. Dalam kaitan dengan dinamika dan gejala pudarnya energy makna dan atau terusiknya pola aktualisasi nilai kearifan ekologis, jika ada, di kalangan masyarakat setempat dalam merawat, memelihara, mewariskannya lintas generasi, dan melestarikan lingkungan keairan tersebut. Dalam konteks budaya merawat alam dan mengawal keharmonisannya dengan lingkungan itu, fungsi bahasa Bali menjadi sangat memengaruhi upaya pelestarian alam dan kebudayaan Bali itu sendiri. Ekoleksikon adalah perangkat kata ataupun istilah yang secara semantic referensial eksternal menandai atau mengkodekan secara verbal, khususnya dalam bahasa local, dalam konteks ini bahasa Bali, sebuah entitas khususnya entitas lokasi kemunculan air yang ada di lingkungan sebagai gambaran kekayaan pengetahuan dan pengalaman berbasis interaksional, interelasional, dan interdependensional antara guyub tutur bahasa Bali dengan lingkungan alam [1]. Perangkat 
kata atau leksikon menandai dan menggambarkan gejala kesemesraan hubungan warga guyub tutur dengan aneka objek ataupun entitas-entitas yang hadir dan atau yang hidup di sekitar mereka, termasuk air, sungai, dan hulu. Ditambahkan oleh [2] bahwa telaah atas khazanah kata secara lebih mendalam, memberikan gambaran tentang nuansa dan derajat keeratan serta kemesraan hubungan antara manusia dengan (entitas-entitas tertentu di) lingkungan. [3] bahkan menegaskan bahwa kata-kata justru menandai dan mewadahi secara sempurna objek-objek yang ada di lingkungan. Jelas, bahwa perbendaharaan leksikon dan istilah dalam suatu bahasa adalah fakta verbal ikhwal kedalaman hubungan warga guyub tutur dan guyub kultur itu dengan keberagaman (entitas-entitas tertentu) yang ada di lingkungan.

Ekoteks, adalah teks-teks pendek dan panjang yang mengandung pesan adicita (ideology) dan nilai ekologis, yang mengacu pada pengetahuan tentang gambaran atau pencandraan (deskripsi), ataupun tentang tata urut verba-verba proses, tindakan, dan prosedur pengerjaan dan atau pengelolaan sesuatu (sumberdaya alam, khususnya air) secara teratur. Dalam kaitan dengan tajuk penelitian ini, teori teks juga dipaparkan secara khusus. Menurut [4], teks adalah bahasa yang fungsional yakni bahasa yang melakukan tugas dalam konteks-konteks sosioekologis tertentu. Seiring dengan konsep tersebut, maka ekoteks adalah bahasa yang melakukan tugas dalam konteks lingkungan tertentu yakni lingkungan guyub tutur tertentu. Dalam kaitan dengan kajian ini secara lebih jelas lingkungan guyub kultur perawat dan pelestari lingkungan mata airhulu sungai, atau juga pengolah pangan lokal-tradisional Bali di sejumlah wilayah dengan variasi social-ekologis. Lebih renik lagi, [5] menjelaskan bahwa teks adalah suatu rangkaian tindak ujar yang direalisasikan dalam bentuk verbal kebahasaan ataupun bentuk-bentuk nonverbal yang mungkin saja berwujud gerakan gestural dan prosodik. Tentu pula secara tekstual verbal, fitur keutuhan dan keserasian (melodi dan rangkaian kata yang tertulis) menjadi fenomena yang menonjol. Di antara sinyal nonverbal yang terkait, gerak bagian-bagian tubuh, anggukan kepala, tangan, meninggikan alis, juga dalam wujud tulisan tentu ada tanda-tanda baca, jelas memperkuat koherensi dan daya semantik kehadiran teks dengan variasi kontekstual khusus sebagai tanda bahasa yang bekerja dalam praktik social-ekologis khususnya.

Bertolak dari kerangka teori di atas, niscaya teks prosedural perawatan dan pelestarian lingkungan mata air-hulu sungai jelas berwujud rangkaian kalimat, dalam hal ini kalimat deklaratif-informatif dalam bahasa Bali. Sebagai bahasa yang sedang berfungsi dan bekerja, niscaya teks verbal itu hadir secara kooperatif pula dengan bahasa nonverbal berupa gerakangerakan tangan tatkala penutur mengolah bahan-bahan dan menggunakan alat-alat sesuai dengan tujuan, manfaat, dan capaiannya. Selain tangan, gerakan bahu, kerdipan mata, bahkan cicipan lidah untuk merasa, semua tanda itu merupaka satu-kesatuan tanda verbal-nonverbal yang bekerja secara kompak dan serasi sebagai "teknologi". Bahasa, khususnya teks procedural menampakkan moment dan gejala teknikal (perawatan dan pelestarian) yang kasat mata dan nyata secara kontekstual-praktikal.Konsep dan teori ekolinguistik (ecolinguistics) mengawali paparan konseptual-teoretik ini. Didefinisikan oleh [6] Ecolinguistics (n.) in linguistics, an emphasis-reflecting the notion of ecology in biological studies- in which the interacting between language and cultural environment is seen as central; also called the ecology of language, ecolinguistics, and sometimes green linguistics, an ecolinguistics approach highlights the value of linguistics diversity in the world, the importance of individual and community linguistics, and the role of language attitudes, language awareness, language variety, and language change in fostering a culture of communicative peace. Lahan kajian ekologi-biologis, kajian yang berfokus atas sesuatu yang hidup di lingkungan tertentu, secara khusus interaksi bahasa dan kebudayaan dengan lingkungan menjadi sangat sentral. Lingkungan (hidup) bahasa, ekolinguistik, bahkan juga linguistic hijau, keberagaman bahasa (termasuk variasi-variasi bahasa yang dikarenakan faktor lingkungan atau faktor bioregion dalam wilayah hidup bahasa 
yang sama, pentingya (variasi) bahasa perorangan dan guyub tutur, sikap (positif), hak hidup setiap bahasa, semuanya menjadi lahan kajian ekolinguistik. Secara khusus disebut pula sebagai linguistik hijau yang secara literal mengacu pada pengertian yang relevan dengan "kehijauan" flora, dan secara metaforis berkaitan dengan lingkungan alam dengan segala yang melatari pula keberagaman budaya. Di dalamnya termasuk keberagaman budaya pangan lokal tradisional berbasis lingkungan lokal pula, tersurat dalam definisi di atas. Secara khusus, linguistic hijau (green linguistics) dalam kajian kritis yang metaforik, menjadi indikator adanya hubungan dengan air sebagai sumber kehidupan. Relasi ikonik "ada ke-(hijau)-an (berarti) ada air, analog dengan ada asap ada api", adalah metafora ekologis yang menandai hubungan bahasa air dengan lingkungan pula.

Ekolinguistik dialektikal yang dikembangkan oleh Bang dan Door, menjadi landasan teoretis dalam membedah satuan-satuan kebahasaan berwujud kata, istilah, kalimat, wacana, dan teks, yang dalam pandangan dialektis ini bahasa disimak sebagai praltik sosial. Dalam perspektif ekolinguistik dialektikal, bahasa sebagai praktik social memiliki tridimensi: ideologikal, sosiologikal, dan biological [7]. Dimensi ideologikal menyiratkan makna bahwasanya dalam praktik social, secara kognitif ada hubungan individu-individu dengan mental kolektif. Termasuk di dalamnya adalah khazanah pengetahuan leksikon dan ungkapan, teks dan wacana, sistem adicita (ideologI) dan sistem ragawi (fisik) secara material, baik yang biotik (manusia, hewan, tumbuhan) maupun yang abiotik (air, tanah, batu, dan sebagainya). Jadi, segala ide dan gagasan kolektif termasuk dalam sistem kognisi masyarakat bahasa dan secara khusus pada guyub tutur (speech community) itu, semuanya hidup secara mental kolektif. Ditambahkan pula, di antara khazanah kata, leksikon, ataupun perangkat istilah misalnya, banyak yang mengandung makna adicita (ideologi). Selanjutnya, dimensi sosiologikal menandai derajat interelasi antarwarga masyarakat bahasa dan antarwaga guyub tutur, menandai tingkat kemesraan relasi dan tingkat kedekatan hubungan yang, apakah penuh cinta, atau sebaliknya kurang, bahkan tidak saling mengenal hingga saling bermusuhan. Dimensi biologikal menyiratkan makna bahwasanya dalam kelhidupan di lingkungan tertentu, sebagai sesame makhluk ekologis, pada hakikatnya manusia hanya dapat hidup dan menjalani kehidupan bersama dengan segala sesuatu yang ada, baik yang bernyawa seperti tetumbuhan dan hewan maupun yang tidak bernyawa, dengan tetap menyelaraskan dan menjamin hidup dan kehidupan secara bersama [7]. Ditegaskan pula dalam tridimensi bahwasa linguistic, secara khusus ekolinguistik dipahami sebagai ilmu tentang kehidupan (linguistics as life-science) dalam arti luas.

Penelitian yang telah dilakukan berkaitan dengan penelitian ekoteks perawatan dan pelestarian lingkungan Mata air- hulu sungai desa Tenganan Pegringsinan. Selanjutnya, penelitian-penelitian ekolinguistik terkait yang telah dilakukan adalah penelitian tentang Beblabadan bahasa bali dan penelitian dimensi praksis dan model dialog leksikon fauna masyarakat sunda (2016) serta penelitian tentang matriks fungsi morfem sesenggakan bahasa Bali. Penelitian lain tentang metaphorical lexicon in maena lyrics of wedding in nias (2017). Lebih daripada itu, terdapat pengabdian masyarakat terkait penelitian dimaksud, yaitu pengabdian masyarakat di tahun 2017 tentang pelestarian leksikon ke puraan. Keseluruhan hasil penelitian dan hasil pengabdian masyarakat diatas akan menjadi rujukan dalam merumuskan konsep ekoteks perawatan dan pelestarian lingkungan Mata air- hulu sungai desa Tenganan Pegringsinan. Adapun tujuan penelitian ini antara lain: Pertama, pendeskripsian konsep konstruksi tekstual dengan dukungan khazanah ekoleksikon terminologik khas penggunaan bahasa Bali dengan fitur variatif kebahasaan bahasa Bali dialek Tenganan dengan keunikannya. Kedua, menemukan makna-makna dan nilai-nilai teks sebagai kekayaan kearifan lokal dalam merawat, menjaga, dan melestarikan sumber daya air dengan lingkungan hulu sungainya. 
Ketiga, pemerolehan fakta tentang tingkat pengetahuan dan pemahaman generasi mileneal di Desa Tenganan sebagai pewaris nilai-nilai kearifan lokal.

\section{Metode Penelitian}

Penelitian ini dilakukan di Desa Tenganan Pegringsingan yang terdiri dari 5 banjar dinas dan 3 desa adat. 5 Banjar dinas yaitu desa Tenganan Pegringsingan, desa Tenganan dauh tukad, desa Tenganan Gumung, desa Tenganan Bukit kangin dan Desa Tenganan bukit kauh. Desa Tenganan Pegringsingan terletak di Kecamatan Manggis Kabupaten Karang Asem Propinsi Bali dengan jarak $17 \mathrm{~km}$ dari Kota Amplapura dan $16 \mathrm{~km}$ dari Denpasar. Luas wilayah desa ini adalah 917,218 ha. Penduduk Desa Tenganan atau dikenal dengan tenganan Pegringsingan adalah 232 kepala keluarga (KK) atau +- 670 jiwa dengan pendidikan mayoritas SD, SMP dan SMA dan pendidikan minoritas Sarjana. Adapun desain penelitian ini adalah cross sectional analitik dimana data dikumpulkan sekali dalam kurun waktu tertentu. Populasi dalam penelitian ini adalah penduduk desa Tenganan Pegringsingan yang berumur 15 sampai 75 tahun. Adapun jumlah sample penelitian ditentukan sebanyak 30 persen dari jumlah populasi. Jumlah 30 persen dianggap sudah bisa berkontribusi normal terhadap permasalahan yang diangkat dalam penelitian. Cara pemilihan sample dilakukan dengan metode bertingkat (multi stage random sampling), yaitu sebagai berikut: (a) Tingkat pertama, memilih 3 dusun dari 5 dusun yang ada di Desa Tenganan Pegringsingan.Pemilihan 3 dusun dari 5 dusun yang ada di desa Tenganan Pengringsingan dengan menggunakan cara acak sederhana (simple random sampling). Tingkat kedua, pemilihan jumlah penduduk dari 3 dusun yang terpilih dengan cara sebagai berikut: (1) Membuatkan list penduduk yang berusia 15-75 tahun dari 3 dusun yang terpilih, (2) Selanjutnya, list penduduk yang berusia 15-75 tahun dibagi menjadi 3 strata. Adapun stratanya adalah kelompok penduduk, yaitu: Strata 1 adalah penduduk yang berusia 15-25 tahun, Strata 2 adalah penduduk yang berusia 26-50 tahun, Strata 3 adalah penduduk yang berusia diatas 50 tahun. Dari list penduduk tersebut dipilih sebanyak 30 persen dari total populasi dengan cara acak berimbang berlapis. Data dikumpulkan dengan metode wawancara langsung menggunakan alat bantu questioner yang sudah distandarisasi. Sebelum questioner bisa disusun, diawali dengan pengumpulan istilah-istilah eko-leksikon dan eko-teks hulu sungai yang didapatkan dari FGD yang melibatkan kelian adat dan klian dinas serta sesepuh desa Tenganan Pegringsingan. Untuk melengkapi kumpulan istilah-istilah eko-leksikon dan eko-teks hulu sungai di desa Tenganan Pegringsingan, dipelajari beberapa data sekunder yang terdapat dalam teks-teks (lisan-tertulis) awig-awig tentang pelestarian hulu sungai Desa Tenganan Pegringsingan. Sebagai pewawancara adalah mahasiswa magister linguistik yang sebelumnya dilatih tentang metode wawancara yang baik. Data diproses dengan bantuan komputer mempergunakan software SPSS dimulai dari pembuatan database, pembersihan data. Selanjutnya, database yang telah bersih dianalisa dengan mempergunakan analisa statistik imperensial yaitu log regresi. Sebagai variable tergantung, pengetahuan tentang ekoleksikon dan ekoteks hulu sungai di desa Tenganan Pegringsingan. Sedangkan sebagai variable bebasnya adalah (1) jumlah tahun pendidikan; (2) umur responden dan (3) jenis kelamin; serta (4) pekerjaan. Sebagai hasil pendekatan kualitatif dengan menggunakan data verbal hasil kerja metode wawancara mendalam, nilai-nilai kedataan dalam bentuk verbal (khazanah leksikon dan istilah serta teksteks procedural) perawatan dan pelestarian lingkungan mata air-hulu sungai, selanjutnya pemaknaan menjadi tumpuan kerja analisis data. Sudah tentu, sebagai data kualitatif maka metode interpretasi atas makna di balik khazanah leksikon dan teks-teks itu menjadi landasan 
kerja analisis. Kerangka makna denotasi (literal) dan makna referensial eksternal [8] membantu membedah dan menemukan makna di balik data verbal itu. Data verbal berbahasa dimaknai pula dalam Bahasa Indonesia sehingga penerjemahan digunakan pula dalam kajian ini.

\section{Hasil Dan Pembahasan}

\subsection{Perangkat Ekoleksikon Terminologik}

Berdasarkan hasil observasi yang dilakukan, maka ditemukanlah ekoleksikon yang ada dalam Hulu sungai desa Tenganan Pegringsinan yang disajikan dalam tabel berikut ini:

Tabel 1. Ekoleksikon Nomina

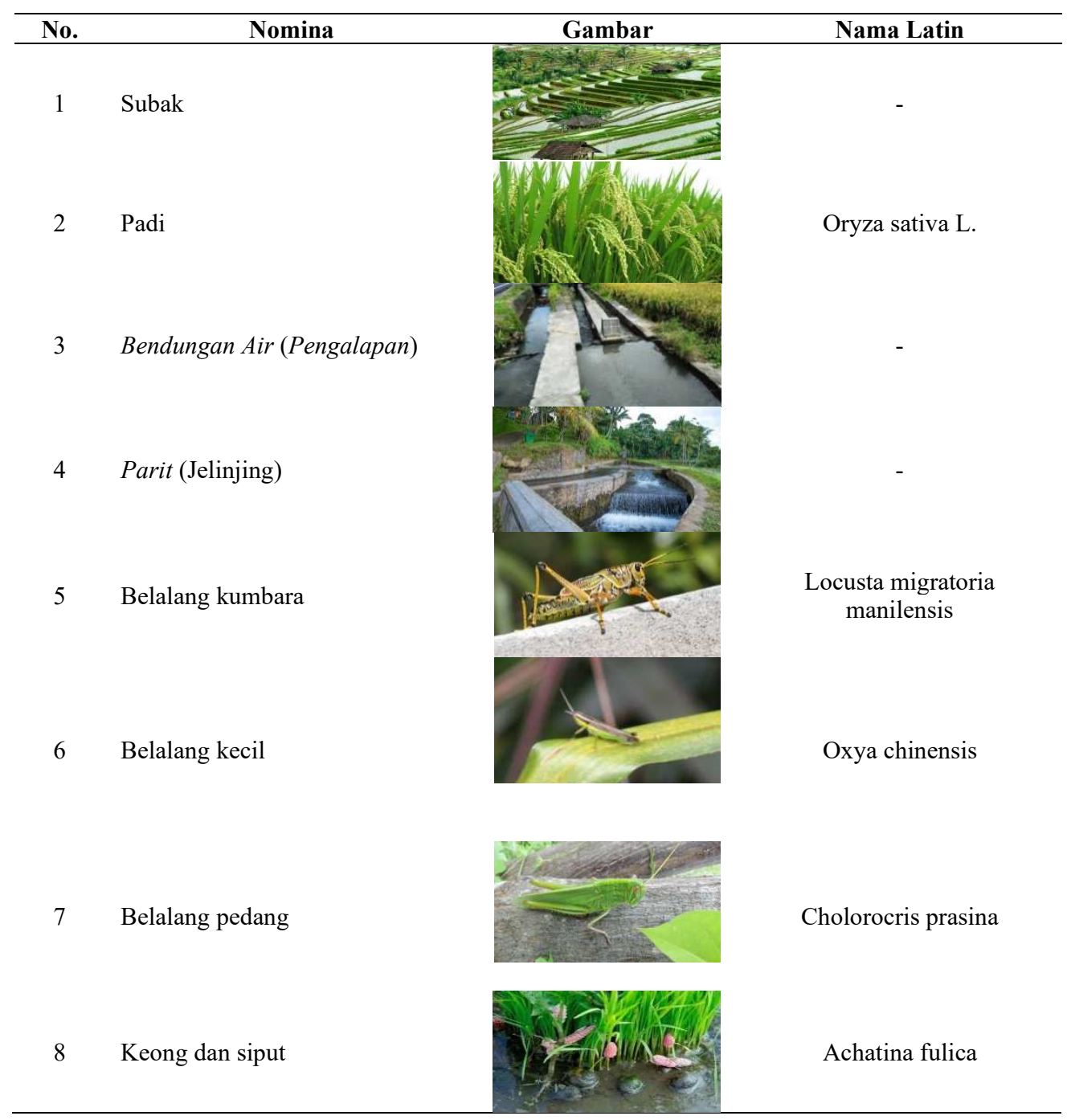




\begin{tabular}{|c|c|c|c|}
\hline No. & Nomina & Gambar & Nama Latin \\
\hline 9 & Kumbang catut & & Xylotropus gideon \\
\hline 10 & Kumbang daun & & Aulacphora spp \\
\hline 11 & Kumbang gajah & & Orchidhopilus atterimus \\
\hline 12 & Ulat bulu & & Lymantridae \\
\hline 13 & Ulat daun & & $\begin{array}{l}\text { handeuleum Doleschallia } \\
\text { polibete }\end{array}$ \\
\hline 14 & Ulat grayak & & Spodoptera spp \\
\hline 15 & Ulat jeruk & & Papilio memnon \\
\hline 16 & Ulat jengkal & & Plusia spp \\
\hline 17 & Ulat kantung & & Psychidae \\
\hline 18 & Ulat keket & & Agrius convolvuli \\
\hline 19 & Ulat kelapa & & Amanthussia phidippus \\
\hline
\end{tabular}




\begin{tabular}{|c|c|c|c|}
\hline No. & Nomina & Gambar & Nama Latin \\
\hline 20 & Ulat kubis & & Crocidolomia pavonana \\
\hline 21 & Ulat kupu & & Lepidoptera \\
\hline 22 & Ulat matahari & & Setora nitens \\
\hline 23 & Ulat raksasa & & Saturnidae \\
\hline 24 & Penggerek batang & & Cerambycidae \\
\hline 25 & Kepik tanaman & & Lygocoris pabulinus \\
\hline 26 & Kutu daun & & Aphididae \\
\hline 27 & Kutu perusak daun & & Myzus persicae \\
\hline 28 & Kutu putih & & Pseudococidae \\
\hline 29 & Penggorok daun & & Liriomyza huidobrensis \\
\hline 30 & Tikus Sawah & & Rattus argentiventer \\
\hline
\end{tabular}




\begin{tabular}{lllcc}
\hline No. & & Nomina & Gambar & Nama Latin \\
\hline & & & & \\
31 & Eceng & & & Monochoria vaginalis \\
\hline
\end{tabular}

Dari tabel diatas, dapat dijelaskan bahwa ekoleksikon nomina yang ditemukan di Hulu sungai desa Tenganan Pegringsinan berjumlah 31 kata, yang mana nomina yang ditemukan tersebut dituliskan dan dijelaskan di dalam tabel diatas. Selain dari ekoleksikon nomina yang ditemukan di Hulu sungai desa Tenganan Pegringsinan, ditemukan pula ekoleksikon verba yang mana verba tersebut dijelaskan dan digambarkan dalam tabel berikut ini:

Tabel 2. Ekoleksikon Verba

\begin{tabular}{|c|c|c|}
\hline No. & Verba & Gambar \\
\hline 1 & Menaman padi & \\
\hline 2 & Memupuk padi & \\
\hline 3 & Memanen padi & \\
\hline 4 & Membajak sawah & \\
\hline 5 & Mencangkul tanah & \\
\hline 6 & Mencabut bibit padi & \\
\hline 7 & Menyemprot padi & \\
\hline 8 & Mengeringkan padi & \\
\hline 9 & Menabur benih padi & \\
\hline 10 & Merendam padi & \\
\hline 11 & Menggiling padi & \\
\hline
\end{tabular}


Dari tabel diatas, dapat disimpulkan bahwa ekoleksikon verba yang ditemukan di Hulu sungai desa Tenganan Pegringsinan berjumlah 11 kata. Ekoleksikon verba yang ditemukan digambarkan dan dijelaskan dalam tabel 5.2. Selain dari ekoleksikon nomina dan ekoleksikon verba yang ditemukan di Hulu sungai desa Tenganan Pegringsinan, ditemukan pula nomina dalam Desa Adat Tenganan Pegringsinan yang tercantum dalam Peraturan Daerah Provinsi Bali Nomor 4 Tahun 2019 tentang Desa adat di Bali, sebagai berikut:

Tabel 3. Nomina dalam Desa Adat Tenganan Pegringsinan

\begin{tabular}{|c|c|c|}
\hline No & $\begin{array}{c}\text { Nomina dalam Desa } \\
\text { Adat Tenganan } \\
\text { Pegringsinan }\end{array}$ & Makna \\
\hline 1 & Desa Adat & $\begin{array}{l}\text { Desa Adat adalah kesatuan masyarakat hukum adat di Bali yang } \\
\text { memiliki wilayah, kedudukan, susunan asli, hak-hak tradisional, harta } \\
\text { kekayaan sendiri, tradisi, tata krama pergaulan hidup masyarakat secara } \\
\text { turun temurun dalam ikatan tempat suci (kahyangan tiga atau } \\
\text { kahyangan desa), tugas dan kewenangan serta hak mengatur dan } \\
\text { mengurus rumah tangganya sendiri. }\end{array}$ \\
\hline 2 & Banjar Adat & $\begin{array}{l}\text { Banjar Adat atau Banjar Suka Duka atau sebutan lain adalah bagian dari } \\
\text { Desa Adat. }\end{array}$ \\
\hline 3 & Krama Desa Adat & $\begin{array}{l}\text { Krama Desa Adat adalah warga masyarakat Bali beragama Hindu yang } \\
\text { Mipil dan tercatat sebagai anggota di Desa Adat setempat. }\end{array}$ \\
\hline 4 & Krama Tamiu & $\begin{array}{l}\text { Krama Tamiu adalah warga masyarakat Bali beragama Hindu yang } \\
\text { tidak Mipil, tetapi tercatat di Desa Adat setempat. }\end{array}$ \\
\hline 5 & Tamiu & $\begin{array}{l}\text { Tamiu adalah orang selain Krama Desa Adat dan Krama Tamiu yang } \\
\text { berada di Wewidangan Desa Adat untuk sementara atau bertempat } \\
\text { tinggal dan tercatat di Desa Adat setempat. }\end{array}$ \\
\hline 6 & Mipil & Mipil adalah sistem registrasi keanggotaan Krama Desa Adat. \\
\hline 7 & $\begin{array}{l}\text { Pemerintahan Desa } \\
\text { Adat }\end{array}$ & $\begin{array}{l}\text { Pemerintahan Desa Adat adalah penyelenggaraan tata kehidupan } \\
\text { bermasyarakat di Desa Adat yang berkaitan dengan Parahyangan, } \\
\text { Pawongan, dan Palemahan yang diakui dan dihormati dalam sistem } \\
\text { pemerintahan Negara Kesatuan Republik Indonesia. }\end{array}$ \\
\hline 8 & Prajuru Desa Adat & Prajuru Desa Adat adalah Pengurus Desa Adat. \\
\hline 9 & Bandesa Adat & $\begin{array}{l}\text { Bandesa Adat atau Kubayan atau dengan sebutan lain adalah Pucuk } \\
\text { Pengurus Desa Adat. }\end{array}$ \\
\hline 10 & Sabha Desa Adat & $\begin{array}{l}\text { Sabha Desa Adat adalah lembaga mitra kerja Prajuru Desa Adat yang } \\
\text { melaksanakan fungsi pertimbangan dalam pengelolaan Desa Adat. }\end{array}$ \\
\hline 11 & Kerta Desa Adat & $\begin{array}{l}\text { Kerta Desa Adat adalah lembaga mitra kerja Prajuru Desa Adat yang } \\
\text { melaksanakan fungsi penyelesaian perkara adat/wicara berdasarkan } \\
\text { hukum adat yang berlaku di Desa Adat setempat. }\end{array}$ \\
\hline 12 & Perkara Adat/Wicara & $\begin{array}{l}\text { Perkara Adat/Wicara adalah setiap persoalan hukum adat dalam urusan } \\
\text { parhyangan, pawongan dan palemahan baik atas dasar permohonan atau } \\
\text { sengketa. }\end{array}$ \\
\hline 13 & Pacalang Desa Adat & $\begin{array}{l}\text { Pacalang Desa Adat atau Jaga Bhaya Desa Adat atau sebutan lain yang } \\
\text { selanjutnya disebut Pacalang, adalah satuan tugas keamanan tradisional } \\
\text { Bali yang dibentuk oleh Desa Adat yang mempunyai tugas untuk } \\
\text { menjaga keamanan dan ketertiban wilayah di wewidangan Desa Adat. }\end{array}$ \\
\hline 14 & Yowana Desa Adat & $\begin{array}{l}\text { Yowana Desa Adat atau Daa Taruna Desa Adat atau sebutan lain, yang } \\
\text { selanjutnya disebut Yowana Desa Adat, adalah organisasi daa- } \\
\text { taruna/pemudi-pemuda di Desa Adat dan/atau Banjar Adat. }\end{array}$ \\
\hline 15 & $\begin{array}{l}\text { Krama Istri Desa } \\
\text { Adat }\end{array}$ & Krama Istri Desa Adat adalah organisasi istri Krama Desa Adat. \\
\hline
\end{tabular}




\begin{tabular}{|c|c|c|}
\hline No & $\begin{array}{l}\text { Nomina dalam Desa } \\
\text { Adat Tenganan } \\
\text { Pegringsinan }\end{array}$ & Makna \\
\hline 16 & Sekaa & $\begin{array}{l}\text { Sekaa adalah berbagai organisasi di Desa Adat yang dibentuk oleh Desa } \\
\text { Adat dan/atau Krama Desa Adat berdasarkan minat, bakat, atau } \\
\text { kebutuhan atas dasar kepentingan yang sama, sesuai dengan yang } \\
\text { dimaksud oleh namanya. }\end{array}$ \\
\hline 17 & $\begin{array}{l}\text { Majelis Desa Adat } \\
\text { yang selanjutnya } \\
\text { disingkat MDA }\end{array}$ & $\begin{array}{l}\text { Majelis Desa Adat yang selanjutnya disingkat MDA adalah persatuan } \\
\text { (pasikian) DesaAdatdi tingkat Provinsi, Kabupaten/Kota, dan } \\
\text { Kecamatan secara berjenjang yang memiliki tugas dan kewenangan di } \\
\text { bidang pengamalan adat istiadat yang bersumber dari agama Hindu } \\
\text { serta kearifan lokal dan berfungsi memberikan nasihat, pertimbangan, } \\
\text { pembinaan, penafsiran, dan keputusan bidang adat, tradisi, budaya, } \\
\text { sosial religius, kearifan lokal, hukum adat dan ekonomi adat. }\end{array}$ \\
\hline 18 & Paruman Desa Adat & $\begin{array}{l}\text { Paruman Desa Adat atau yang disebut dengan sebutan lain adalah } \\
\text { lembaga pengambil keputusan tertinggi menyangkut masalah prinsip } \\
\text { dan strategis di Desa Adat. }\end{array}$ \\
\hline 19 & $\begin{array}{l}\text { Pasangkepan Desa } \\
\text { Adat }\end{array}$ & $\begin{array}{l}\text { Pasangkepan Desa Adat atau yang disebut dengan istilah lain adalah } \\
\text { lembaga pengambil keputusan menyangkut masalah teknis operasional } \\
\text { sebagai pelaksanaan keputusan Paruman Desa Adat. }\end{array}$ \\
\hline 20 & Tri Hita Karana & $\begin{array}{l}\text { Tri Hita Karana adalah tiga penyebab timbulnya kebahagiaan, yaitu } \\
\text { sikap hidup yang seimbang atau harmonis antara berbakti kepada } \\
\text { Tuhan, mengabdi pada sesama umat manusia, dan menyayangi alam } \\
\text { lingkungan berdasarkan pengorbanan suci (yadnya). }\end{array}$ \\
\hline 21 & Sad Kerthi & $\begin{array}{l}\text { Sad Kerthi adalah upaya untuk menyucikan jiwa (atma kerthi), menjaga } \\
\text { kelestarian hutan (wana kerthi) dan danau (danu kerthi) sebagai sumber } \\
\text { air bersih, laut beserta pantai (segara kerthi), keharmonisan sosial dan } \\
\text { alam yang dinamis (jagat kerthi), dan membangun kualitas sumber daya } \\
\text { manusia (jana kerthi). }\end{array}$ \\
\hline 22 & Awig-Awig & $\begin{array}{l}\text { Awig-Awig adalah aturan yang dibuat oleh Desa Adat dan/atau Banjar } \\
\text { Adat yang berlaku bagi Krama Desa Adat, Krama Tamiu, dan Tamiu. }\end{array}$ \\
\hline 23 & Pararem & $\begin{array}{l}\text { Pararem adalahaturan/keputusan Paruman Desa Adat sebagai } \\
\text { pelaksanaan Awig-Awig atau mengatur hal-hal baru dan/atau } \\
\text { menyelesaikan perkara adat/wicara di Desa Adat. }\end{array}$ \\
\hline 24 & Dresta & $\begin{array}{l}\text { Dresta adalah adat kebiasaan/tradisi yang diwarisi secara turun temurun } \\
\text { dan masih ditaati oleh Desa Adat. }\end{array}$ \\
\hline 25 & $\begin{array}{l}\text { Wewidangan atau } \\
\text { Wewengkon }\end{array}$ & $\begin{array}{l}\text { Wewidangan atau Wewengkon, yang selanjutnya disebut Wewidangan } \\
\text { Desa Adat adalah wilayah Desa Adat yang memiliki batas-batas } \\
\text { tertentu. }\end{array}$ \\
\hline 26 & Padruwen Desa Adat & $\begin{array}{l}\text { Padruwen Desa Adat adalah seluruh harta kekayaan Desa Adat baik } \\
\text { yang bersifat immateriil maupun materiil. }\end{array}$ \\
\hline 27 & $\begin{array}{l}\text { Labda Pacingkreman } \\
\text { Desa Adat }\end{array}$ & $\begin{array}{l}\text { Labda Pacingkreman Desa Adat yang selanjutnya disebut LPD adalah } \\
\text { Lembaga Perkreditan Desa milik Desa Adat yang berkedudukan di } \\
\text { Wewidangan Desa Adat. }\end{array}$ \\
\hline
\end{tabular}

Dari tabel 5.3 diatas, dijelaskan bahwa nomina ada dalam Desa Adat Tenganan Pegringsinan berjumlah 27 kata.

\subsection{Pelestarian Fungsi Pengelolaan, Perawatan, dan Pelestarian Lingkungan Khusus Mata Air-Hulu Sungai Di Kawasan Desa Tenganan Pegringsingan}

Hasil interview dengan sesepuh dan apparat banjar dinas dan banjar adat Desa Tenganan Pegringsingan menunjukkan bahwa upaya fungsi pengelolaan, perawatan dan pelestarian lingkungan khusus mata air hulu sungai di kawasan Desa Tenganan Pegringsingan mengacu 
pada peraturan daerah propinsi Bali Nomor. 11 Tahun 2009 tentang pengelolaan Daerah aliran sungai terpadu Propinsi Bali. Dalam Peraturan daerah tersebut sudah dijelaskan ketentuan umum khusus serta sangsi yang akan dikenakan kepada warga terkait dengan pelanggaran pengelolaan daerah aliran sungai terpadu di desa Tenganan Pegringsingan, yang meliputi satu kesatuan ekosistem yang utuh dari hulu sampai hilir yang terdiri dari unsur-unsur utama tanah, vegetasi, air maupun udara. Untuk menjaga kelestarian istilah istilah hulu sungai, pengelolaan daerah aliran sungai (DAS) dilakukan secara terpadu antara warga dan aparat desa guna menjaga manfaat dan lestari, kerakyatan dan keadilan, kebersamaan, keterpaduan, keberlanjutan, berbasis masyarakat, kesatuan wilayah dan ekosistem, keseimbangan, pemberdayaan masyarakat, akuntabel dan transparan serta pengakuan terhadap kearifan lokal. Dalam pelaksanaannya, pelestarian istilah-istilah hulu sungai di desa Tenganan Pegringsingan dilakukan dengan cara pembinaan dan pemberdayaan dalam mengelola DAS bertujuan untuk meningkatkan kapasitas dan kapabilitas institusi, pemerintah, swasta, masyarakat dalam perencanaan, pengorganisasian, pelaksanaan, monitoring, evaluasi serta pendanaan. Pembinaan dimaksud dilakukan oleh dan antar Pemerintah secara berjenjang maupun oleh dan antar swasta dan institusi masyarakat melalui pemberian pedoman, supervise dan konsultasi, pendidikan dan pelatihan, pemberian bantuan teknis, sosialisasi serta penyediaan sarana dan prasarana. Sedangkan pemberdayaan dilakukan oleh pemerintah, swasta maupun institusi masyarakat kepada masyarakat yang mendiami DAS dan sekitarnya secara transparatif melalui pendidikan dan pelatihan, penyuluhan, pendampingan, pemberian bantuan modal, advokasi serta penyediaan sarana dan prasarana. Sedangkan monitoring dan evaluasi terhadap pelaksanaan kegiatan ini dilakukan melalui kegiatan pemantauan, pengawasan dan penertiban dalam kawasan budidaya dan lindung, baik dari bagian hulu, bagian hilir dan bagian tengah DAS. Monitoring tersebut dilakukan melalui kegiatan pemantauan, pengawasan dan penertiban dalam kawasan budidaya dan lindung, baik pada bagian hulu, tengah dan hilir. Evaluasi dilakukan untuk menilai keberhasilan dan perumusan rencana tindak lanjut pengelolaan DAS terpadu.

\section{Kesimpulan}

Berdasarkan rumusan masalah yang diangkat dalam penelitian ini, simpulan yang didapatkan dari hasil analisis adalah sebagai berikut :

1. Pada kajian eko-teks di Hulu sungai desa adat Tenganan Pegringsinan, ditemukan bahwa terdapat 31 ekoleksikon nomina. Ekoleksikon nomina ini dijelaskan dan digambarkan dalam Tabel 5.1. Selain dari ekoleksikon nomina yang ditemukan, ekoleksikon verba juga ditemukan di Hulu sungai desa adat Tenganan Pegringsinan. Ekoleksikon verba yang ditemukan berjumlah 11 kata. Dalam Peraturan Daerah Provinsi Bali Nomor 4 Tahun 2019 tentang Desa adat di Bali, disebutkan bahwa terdapat pula nomina dalam desa Adat Tenganan Pegringsinan yang digunakan. Nomina dalam desa adat Tenganan Pegringsinan tersebut berjumlah 27 kata.

2. Perlu kerjasama berbagai pihak untuk melestarikan eko-teks yang ada di desa Adat Tenganan Pegringsinan.

\section{References}

[1] A. M. Mbete, Penuntun Singkat Penulisan Proposal Penelitian Ekolinguistik. Denpasar: Vidia, 2013.

[2] E. Sapir, "Language and Environment," in The Ecolinguisics Reader: Language, Ecology and 
Environment, A. Fill and P. Muhhausler, Eds. London: Continuum, 2001.

[3] G. Steiner, "Language and Gnosis," in The Ecolinguistics Reader: Language, Ecology and Environment, A. Fill and P. Muhhausler, Eds. London: London Continuum, 2001.

[4] M. A. . Halliday and H. Ruqaiya, Bahasa, Konteks, dan Teks: Aspekaspek Bahasa dalam Pandangan Semiotik Sosial. Yogyakarta: Gajah Mada University Press, 1992.

[5] F. Conish, Text and discourse as context: Discourse anaphora and the FDG Contextual Component. University of Westminster, 2008.

[6] D. Crystal, A Dictionary of Linguistics and Phonetics, 6th ed. United Kingdom: Blackwell Publishing, 2008.

[7] J. C. Bang and J. Door, Eco-Linguistics: A Framework. 1993.

[8] J. W. . Verhaar, Asas-Asas Linguistik Umum. Yogyakarta: Gadjah Mada Univerity Press, 2006. 